Fingland in the autumn, and in the following spring Henry Simeonis seems to have been again in Oxford. ${ }^{12}$ In 1246 Henry III granted to the friars minor an island which he had bought from Henry son of Henry Simeon. ${ }^{\text {ts }}$ Many years later many of the Oxford scholars seceded to Northampton: on 12 Maroh 1264, the king suspended the university during the session of his council at Oxford, ${ }^{14}$ and on the 25 th he issued letters patent reciting that, whereas he had ordered

that if it should appear . . that the chancellor and university would be content that Henry son of Henry Simeonis, who withdrew for the death of a man, would return to Oxford and stay there, so that the university should not retire from the said town on account of his staying there; then they should permit him to return without impediment and have the king's peace ; the king . . . has pardoned the said Henry the said desth, on condition that he stand his trial if any will proceed against him, and has granted that he may return and dwell there so long as be be of good behaviour and that the university do not withdraw from the town on ascount of his return and the death of the said Henry.15

From this it appears that Henry son of Henry Simeonis was charged with homicide, and that his alleged crime was a cause of the secession of the university to Northampton. When it returned to Oxford, the king was a prisoner and the country was in the hands of his enemies. ${ }^{10}$ It was not to be expected that the Bcholars would pay attention to the order of 25 March requiring them to permit Henry the son of Henry Simeonis to come beok peaceably to Oxford. Naturally they resumed their former attitude of hostility to him : they would never consent to his reconciliation. This, it seems to me, was the origin of the ostb, which was maintained until $1827 . \quad$ Rkgivald L. Pools.

\title{
Copyhold Tenure at Felsted, Essex
}

TyE manor of Felsted in Essex, that is, the chief manor of that parish, which had its manor-house, 'the Bury,' close by the church, belonged in 1576 to Robert, second Baron Rich of Leeze. In that year he caused an exhaustive survey to be made of it by Edward Worsely, gentleman, as well by walking the bounds of the manor as by the evidence, taken on oath, of a manorial jury of fiften and of other tenants. The greater portion of this record is still extant, in an excellent eighteenth-century transcript, undoubtedly made, for professional purposes, under the direction of a steward of the manor. This manuscript is the property

13 Red Boak of the Exhequer, p. 1070, 1890.

1222 April a. 29, Calendar of Patent Rall, 1232-47, p. 451, 1906.

14 Cal. of Patent Rollo, 1268-66, p. 307, 1910.

11 The order for the return is dated $30 \mathrm{May}$ (ibid. p. 320). 
of Alfred Hills, Esquiro, of Braintree and Bocking; consists of 156 folio pages, of olose and neat writing, thirtyeight to forty lines to a page, with some unfolioed leaves; and contains the boundaries of every freehold and copyhold of the manor, with a statement of the manorial customs. The concluding portion of the originil survey, which dealt with the demesne-lands, is not known to be extant. The customs of this manor are of especial interest, as showing copyhold tenure in its nearest approach to froehold.

Felsted Manor had been conferred, at the dissolution of the monasteries, on Sir Richard Rich, afterwards (1547) Baron Rich of Leeze (Morant's Essex, ii. 416). Since about 1415 it had been the property of the abbess and nuns of Sion in Middlesex, of Henry V's foundation. The Crown had acquired it on the seizure, by Edward III, of the lands of alien priories. Originally, by grant of William I, it had belonged to the Norman nunnery of Holy Trinity, Caen. The fact of long ownership by a foreign nunnery no doubt explains the anomalies found among its customs.

Its law of succession was not that recognized by the law of Finglend :

The custome of the mannor is that the eldest son of every customary tenant within the mannor is next heir unto his father or other ancestors; and, for default of such issue male, then the eldest daughter shall be only hoir. And allbeit there be three or four daughters more, yet she only (being eldest) shall be heire of such customary lands, and not to hold the same in coparcenary with the rest according to the course of the common law (p. 149).

Its tenants enjoyed to the full the large immunities granted by the Crown to the estates of religious ladies. They claimed, among many other exemptions from duties to the Crown, to be free from

(a) the suite of the county sheriff's turne, and hundred; (b) all things that belong to the office of the clerke of the king's market; $(c)$ all aids to be given to the sheriffe; (d) all payments towards the expence of choosing knights of the shire; (e) that noe sheriffe shall arrest any tenent, by writt, precept, or other processe, within the county where they are reaident, although they be without the bounds of the mannor, but that Lord Rich may remand them to the mannor to receive execucion there; $(f)$ that the perveyor of the king's household shall not take any of the goods and chattells of Lord Rich or any of his tenents or residents for the use of his majestie's household ; and $(g)$ that it shall be lawfull to resist all his majestie's officers whatsocver who shall goe about to doe anything contrary to the customes aforesaid, and to make rescues as the case shall require (p. $147 \mathrm{~A})$. Also there belongeth to the mannor an especiall priviledge or libertie that no tenaunte whatsoever belonging to this mannor can or ought to be arrested at any time or times within the towne of Braintree [i.e. the natural market-town of the manor] for or upon any debt or trespas, except for felonie murder or treason (p. 151). 
The long-continued foreign ownership, in early times, similarly accounts for the emancipation of the tenants from most of the obligations imposed on copyhold lend in England. The Norman nunnery cscaped frequent troublo and legal expenses by accepting fixed dues in place of variable dues, and even by surrendering ordinary manorial claims. A list of suoh exemptions follows.

(i) Copyhold land elsewhere was subject to entrance-fine on each change of tenant. The amount of this fine was fixed by bargain, on each occasion, between the steward (acting for thelord of the manor) and the new tenant. At Felsted the entrance-fine was 8 'fine certain ', i.e. fixed, at the rate of 108 . for the yardland, 58 . for the half-yardland, and $2 s .6 \mathrm{~d}$. for the quarter-yardland.

Every customary tenent of one yard-land there, after every alienacion, exchange, or death, shall yeild to the Lord of the mannor for the fine of his yardland, of certainty, tenn shillings (p. 147).

Where the copyhold was ancient, but not of the nature of a yardland, or a determinate fraction of the yardland, the entrancefine was one year's quit-rent, exactly as 'relief' was paid on admission to freehold.

Every customary tenant, commonly called an ancient customary tenant, of the manor, after every alienacion, exchange, or death, shall yeild to the Lord of the fine for his land the value of one year's rent of assize, and not above (p. 147).

Where the copybold was a tenure created by the custom called 'undersettling', presently to be noticed, the entrance-fine was assessed by the acreage.

Every tenant customary, commonly called an undersetling tenant after every alienacion exchange or death, shall yeild to the Lord for the fine of his lands, for every acre there of two pence and not above (p. 147).

Some copyholds were recognized to be enclosures from the 'waste', i. e. common-land of the manor, or grants on copyhold conditions of demesne-land. Such of them as were long prior to the survey were allowed the benefit of the custom, and paid only one year's quit-rent as entrance-fine. The more recent of them the steward wished to subject to ordinary copyhold fine 'arbitrable at the Lord's will' (p. 148).

(ii) Copyholders were almost everywhere strictly bound to keep their buildings in repair. Even if the buildings were no longer required, leave had to be obtained, and a fee paid to the manor, for taking them down. From this Felsted tenants were quite exempt.

They may suffer their customary tenements and buildings to the same belonging, either to fall into utter ruine and decay, or else to sell away the timber thereof so decayed at their like liberties and pleasures, without 
any danger of forfeiture of their estates, because (as they alledge) they hold their tenements and lands by the tenure of ancient demesne (p. 148).

(iii) In ordinary copyholds timber growing on the land belonged to the manor, and to fell any of it the copyholder had to obtain leave and pay fees and agreed-upon share of profite. At Felsted the copyholder had absolute right to all timber on his land.

Customary tenants bave and may from time to time not only fell all woods, underwoods, and trees, as well meete for timber as otherwise, of what kind soever they be, growing and being in and upon their severall Copyhold lands, and the same to carry away and sell at their own liberties and pleasures, without any impeachment of wast, or any other forfeiture made whatsoever (p. 148).

(iv) Ordinary copyholds were held under a general threat of forfeiture for any breach of manorial custom. At Felsted the conditions of forfeiture were very narrowly defined, and the practical effect of forfeiture reduced to a minimum.

Moreover (as they say) there is no maner of forfeiture incident to their estates, except only for denyall of their annuall rents, services, or suite of court to the Lord's Court Baron from three weekes to three weekes upon lawful summons.

If the Lord shall at any time take any such advantage of forfeiture of their estates, and thereupon is awarded a seisure upon the lands to the Lord's use, neverthelesse their custome is that the Lord is, at the next court aiter, upon the tenant's petition, to regrant the same lands unto such tenant soe offending in as large and ample manner as he did hold the lands before the forfeiture, and that thereupon the tenant ought to pay unto the Lord one yeare's rent of assise, for and in name of a fine, and not above (p. 149).

(v) An ordinary copyholder could not let any part of his land for more than one year, without leave asked and paid for. Nor could he sell any part, except by complete surrender into the hands of the lord, who then (in theory) made a new grant of it to the purchaser. At Felsted binding leases for terms of three years were granted by copyholders at their own free will; and portions of such copyholds as were yardlands, or fractions of original yardlands, were freely sold by copyholders, according to the custom called ' undersettling', subject to an annual quit-rent to the copyhold, and suit of court to the manor.

Every customary tenant may from time to time sell and lett the customary tenancies, without license of the Lord, to any person or persons whatsoever for and during the terme of three yeares (p. 149).

Any customary tenant, being a yardland, halfeyardland or quarteryardland tenant, may at any time surrender into the Lord's hands any part or parcell of his customary lands to the use and behooffe of any other 
person whatsoever, to have and to Lold such part or parcell of land (ace surrendred) to the use of him to whom the surrender is made, and to his heires for ever, reserving to the vendor and his heires for ever an annuall rent to be paid yearly to his customary tenement and lands by him and his heires unto whose use the surrender was made; and every such tensint thereupon is called a tensnt of undersetling (p. 150).

(vi) The only impost on copyhold land in Felsted manor which was not also borne by freehold was the heriot, and even this was limited to the yardland and fraction of yardland holdings, and could be claimed of most of those only if the holding were in the tenant's own actual nccupation, and not mortgaged or leased.

Every of the yardland, halfeyardland, and quarteryardland tenents of the mannor, are to yeild an beriot, vizt. his best beast, to the Lord for their lands at the tyme of their death, only if soe be that any such tenent or tenents doe dye seised of surch estate (p. 147).

But ancient customary tenants, undersettling tenants, copyholders of waste or formerly demesne-land are

clearly discharged from time to time from yeilding or paying any beriot or heriotts whatsoever (p. 147).

The reservation just mentioned did not apply to five of the half-yardlands,

the severall tenants whereof, by force of the custome of the manor, doe yeild to the Lord, at the time of their deuths, a severall heriott, viz. his or their best beast, without [the qualification] ' that any such tenant or tenants die seised of any such customary lands (yea or nay) ', as is before expressed (p. 150).

(vii) There were, however, some copyholds which continued subject to an old burden, reminiscent of their original serf condition.

Certain customary tenants, commonly called the tenants of the Swinwick-hold, are bound from time to time, at their own proper costs and charges, to repair and maintaine, as often as need shall require, the Lord's hoggs-cote or swine-house, scitlute lying and being near to the scite of the mannor (commonly called Folater-bury), in and by all manner of sufficient reparacions (p. 150).

Among the unfolioed sheets in the manuscript are notes of the statements of tenants of the manor made, 1587, to 'Mr. Cordall ' (brother of Sir William Cordell, master of the rolls 1557-81), acting as commissioner for the second Lord Rich on his succeeding to the estate. They then set out their privileges very curtly and incisively :

For our wood and timber, by our Custome, we may doe what we will.

For our houses of our coppie-Jiolds wee may take them down and doe with them what we will. 
For our customarie lands our fine is a yeare's rent (what we pay the Lord by the year).

For our halfeyardland (2xx. acres is halfe a yard) the fine to the Lord is $\mathbf{8 8}$.

For a licence to let our lands above three ycars (our custom is) iiiid. a year so many years as we will bave it. Our custom is to let it for three years without a lycenso.

The lord of the manor was also rector of the parish. The troublesome tithe of hay, which in other parishes led to much litigation, was here commuted for a charge of so much per acre yearly from sixty-seven specificd patches of meadow. The richer meadow-land by the streams paid $4 d$. an acre; the poorer apland meadow only half that rate.

Our custome is, for River mead, iiiid. an acre; for Land mead, iid. an acre for tythe.

A. Chark.

\section{The Names of Zermatt}

IT may interest some readers of this Review to have a short account of the history of the names that have been borne by this celebrated Alpine village. It must first of all be stated that in reality this village has never had but a single name, though that has assumed two forms, one being Romance and the other German, so that one translates, as it were, the otherPraborgne or Zermatt-each of theso forms, however, being spelt in many divers fashions. The German form does not appear till 1495 on a map, or 1544 in a text, but naturally may have boen employed on the spot long before, since, as usual, local information is lacking on such a point. The reason of this sudden change - the two streams flowing henceforth together, though not absorbing each other-is not known with certainty. But very probably it may be assigned to an alteration in the language (and therefore naturally of the race also) of the inhabitants of the village-a Romance-speaking folk would then have been gradually replaced by a German-speaking colony. It is well known, as a matter of fact, that in the Upper Vallais such changes have been known. In the case of Zermatt there are still extant certain traces (quite apart from the name of the village itself) which seem to show that originally it was inhabited by a Romance-speaking race- - so the names of 'Aroleit', close to Zermatt, of 'Randa, ' and of 'Chouson' '(later Teutonized into 'Gasen'-the village is now called St. Niklaus, from the dedication of its church)-in fact the name 'Chouson' occurs in 1218 already, ${ }^{1}$ some sixty years before the earliest known documentary

1 Gremeud, Documents relatifa à $r$ Histoire du Vallais, i. 205. 